\title{
Secondary Device Identifier
}

National Cancer Institute

\section{Source}

National Cancer Institute. Secondary Device Identifier. NCI Thesaurus. Code C101724.

An alternate identification number for a device. 